\title{
Stylistic description of phraseological connotation
}

\author{
Dr. Trushev Aytmukhamet Kassymbaevich \\ S. Toraighyrov Pavlodar State University, Pavlodar, Lomov Str., 64, 140000. Kazakhstan. \\ trushev56@mail.ru \\ PhD Zhumabekova Beibytnur Kaparovna \\ S. Toraighyrov Pavlodar State University, Pavlodar, Lomov Str., 64, 140000. Kazakhstan. \\ beibitnur@mail.ru \\ PhD Karipzhanova Gulnaz Tokenovna \\ S. Toraighyrov Pavlodar State University, Pavlodar, Lomov Str., 64, 140000. Kazakhstan. \\ adon@mail.ru \\ PhD Karipzhanova Ainur Oralovna \\ S. Toraighyrov Pavlodar State University, Pavlodar, Lomov Str., 64, 140000. Kazakhstan. \\ ainurok1974@mail.ru \\ Prof., Dr. Abikenova Gulnat Tokenovna \\ Kazakh Innovative University of Humanities and Law, Semey, Abay Str. 107, 490050. Kazakhstan. \\ abikenova-gt@mail.ru
}

\section{ABSTRACT}

This article considers the issues of phraseological connotation in a literary text, phraseology issues from the perspective of cultural linguistics, different approaches to phraseological units classification in contemporary linguistic studies, functionalstylistic and emotional-expressive features of phraseological units in a literary text. By phraseological unit we mean fixed combinations of words characterized by constant lexical composition, grammatical structure and meaning that is known to the language speakers and that is not derived from the meaning of the constituent components.

\section{Keywords}

phraseological connotation, phraseological units classification, literary text, functional-stylistic and emotional-expressive features of phraseological units, cultural experience, linguistic view of the world, national worldview;

\section{Academic Discipline and Sub-Disciplines}

Philology; Cultural Studies, Linguistics;

\section{SUBJECT CLASSIFICATION}

Philology; Phraseology

\section{TYPE (METHOD/APPROACH)}

Literary Analysis; Survey

\section{INTRODUCTION}

Identification of sets of concepts, which form linguistic view of the world, is considered from the perspective of cultural linguistics and pragmatics. Idioms allocate phraseological units which differ with figurativeness and emotionality. In the latest research phraseology is regarded as a part of linguistic view of the world, area of national worldview. The object of our study is phraseological units in Mashkhur Zhusup's works, transformation of national phraseological units, methods of author's innovation. The aim of the article is to describe the structural-semantic and stylistic features of the phraseological units in a literary text, to identify and describe the conditions and characteristics of the implementation of these units in functional styles of contemporary Kazakh language.

\section{MAIN PART}

If contemporary cognitive linguistics proves the relationship of determination of characteristic issues of the word meaning and its concept with human consciousness, its understanding, at the level of the flight of the imagination, then stylistics demonstrates the way to present it correctly to the artistic-cognitive point of view. Stylistics in its field of study does not adhere to any certain limited level, but it is correlated with other sciences. Studying stylistics as a science discussed such fields as pragmatics, communicative linguistics, speech functions theory, psycholinguistics, text linguistics, linguistic poetics, logic, text analysis, cognitive linguistics, etc. , which are related to various aspects of the object of this science.

The main characteristics of phraseological units, firmly fixed in the system, are the following: complete closeness of stylistic connotation figurativeness or composition to pragmatic-stylistic purpose. The history of the phraseology development is described through continuous and constant interest of scientists to studying phraseological units in literary texts, because with the communicative and pragmatic point of view fiction phraseological units are an inexhaustible treasure to explore. N. McLean writes: «... here we should not focus on the study of language structure for the structure 
itself, but how a writer uses such structure to influence his readers, what he shows them, what he persuades them of or from» $[1]$.

Choosing stylistic methods and actions, the author intends to have an effect on the reader. Author's choice of language units, his thinking is directly related to the effective achievement of certain pragmatic goals in his subconscious. At first, pragmatics includes stylistics, text linguistics and communicative linguistics. One of the main goals of pragmatics is to explain the use of a word. Pragmatic meaning defines the world of communicants and their functions.

Ch. W. Morris says on the impact of cognitive linguistics and psycholinguistics during the use of pragmatics: «Pragmatics studies the purpose of a person in a particular situation in conversation. Text linguistics studies the use of language units in the relationship of the addresser and the addressee in order to make a specific impact and influence». [2]

Consequently, pragmatics, connecting conversational language experience with the life of ordinary people and using stylistic methods and means, teaches to understand the cognitive basis of the peculiarities of perceiving people's world as well as national and cultural traditions.

It is possible to find some features in the use of phraseological units in fiction literature. The use of phraseological units in order to achieve stylistic purpose is connected with contribution of author's own manner using the wealth of the language of folklore, and secondly, in accordance with the era, the society, the social position of people it is closely connected with displaying social life. Fiction literature is a mirror of its era, and phraseological units play a special role in the displaying the life of that era and touching, sensual parallels (experiences). Artistic methods used in idioms are applied specifically to reduce their content by means of rhyme, rhythm, words implemented in their composition and sound vowel harmony. They are used in order to give special stylistic coloring to the expression. All this is actually pragmatic tasks. In general language of fiction literature conforms to the standards inherent in artistic expression of any nation. And national standards are a figurative, artistic language originating from ancient oral folk literature and filled with the row of synonymous doublets.

In this regard P. Fry writes: «The usual form of phraseological units changed and change of their components places does not cause any harm to their meaning, but, conversely, it pursues certain stylistic purpose». [3]

Phraseological collocations are the combinations of expressive, figurative words used to convey the author's thoughts more impressively. Deviation from the standards of phraseological collocations will not immediately be successful and incorrect attempt. On the contrary, a deviation from the standards with a specific purpose can have a huge impact on the reader. In this regard R. E .Asher says: «Pursuing a certain goal, the deviation from the standard, we call a pragmatic deviation» [4].

Therefore, formation of phraseological units potential, occasional basis in the text, study of the possibilities of linguistic aspects are closely connected with the pragmatics that deals with the study of issues with the greatest impact on the addressee in the conversation. Consequently, the phraseological units in fiction literature are figurative and descriptive method, give artistic grace, are used to transmit emotional sarcasm, demonstrate a wealth of feelings, and at the basis of each there is a pragmatic direction and additional hidden meaning.

Stylistic effect of contextual occasional phraseological collocations is shown in the expressive function of phraseological expressions which are specific to each nation. Speaking about the formation of a national characteristic of formation of phraseological units, you must also not forget the role of the existing traditions and customs, which appeared together with the national outlook and view on the world.

So, the author of the work, freely using idioms and phrases, preserved and collected for centuries in the minds of the people, on their basis creates his author's phraseological units corresponding his own outlook and style.

It is known that the basis of figurative language units is the permanence of the unity of content and constant structure of phraseological units. But in colloquial speech there are some changes in the meaning and form of idioms. These changes give special expressive nature to functional-semantic properties of phraseological units. In order to enhance the expressiveness of phraseological units applied stylistic devices change their usual meaning and with occasional viewpoint change the semantic meaning of idioms. Author's phraseological units, which have been changed, sometimes can be used in another figuratively meaning instead of already formed constant meaning. Such aptitude of phraseological units to changes, their development from a semantic point of view, and their transformation with lexical and grammatical point of view is connected with the style of the writer and mastery of verbal transfiguration.

L. I. Royzenzon writes: «In a fiction work to some extent related to the intelligence of the writer, there is some self-will, some formal deviation from the general standard, agrammatical (breach of the system, certain laws), abnormal (unusual, different from formed) metabasis (usage of parts of speech in other functions) change» [5].

The aptitude of phraseological units to changes in the work shows all the ease and freedom of style and artistic language inherent to the author. The purpose of phraseological changes is manifested in varying degrees, one takes stylistic importance, the other has a property of «breach» for rhyme, and the third pursues the aim to give additional meaning.

The indisputable fact is that the writers and poets have made a huge contribution to the development of the national language. They bring new collocations and great rhymes to the language. For example, the language of the founder of 
Kazakh written literature, Abai, proves everything mentioned above. Abai's Words of Edification became proverbs and sayings, popular quotations, turned into the common property of nation, developed our literary language.

Among figurative means of Mashkhur-Zhusup Kopeev's works phraseological units are one of the linguistic methods you should pay special attention to. These phraseological units vary in connotation and stylistic properties. Author's selection of these phraseological units depends on the direction of the topic and the main idea of the work. Some idioms are applied several times by author. But this repetition in each case is used with a certain stylistic purpose and assumes a different character because the author with a great skill gives a new meaning to phraseological units, exposes them to process and transforms them. Such phraseological units reflect the author's outlook, the peculiarity of his perception, his own conclusions, the inner world, and draws attention to the features which are not peculiar to anybody. Earlier this topic was discussed in A. O. Karipzhanova's works [6].

P.Fry divides features of use of phraseological units in the epic works into two areas. The first are phraseological units which are not changed in meaning and form. The second are groups of phraseological units which are built by means of stylistic means, undergo changes in form and meaning and are divided into types formed as a result of changes of phraseological units:

1) Phraseological unit with an additional component adapted into its structure;

2) Phraseological unit with an additional component added into its structure;

3) Phraseological unit which components are shortened (ellipsis);

4) Phraseological unit which component is replaced by another word;

5) Phraseological unit which in itself is shortened and adapted (contamination) [3].

We took the basis of scientific principle proposed by P. Fry to define pragmatic-stylistic characteristics of phraseological units used by Mashkhur Zhusup.

1. They take new meaning when a modified nation-wide form of phraseological units is used. Proverbs and sayings are the mirror of people's life. Most of them are a genuine result of life experience, summary of certain actions. In M. Kopeev's works, an artistic word master, there are many proverbs and sayings.

"Oner aldy - qyzyl til»; "Qoinyndy olgen sarttyn nany bar»; "Olgen qyzdan dametken omir-tentek»; «Ai - kirsiz, Qudai-minsiz»; "Tabar eshki egizdi, it segizdi»; "Muratqa okpelep zhurgende saqal shyqty»; "Oiynda ozgan - shynynda ozar», «Balaly ui - bazar»; «Myn oliden bir tiri artyq»; "Assyl - tastan, oner - zhastan».

Mashkhur Zhusup's works reveal pragmatic-stylistic features of poet's language through figurative and expressive collocations which are assonant to proverbs and sayings or transformed in order to obtain meaning of proverbs and sayings.

Proverbs and sayings as well as phraseological units express broad thought, they are represented by logical structures that convey basic idea and linguistic phenomena and are an excellent model for the conclusions. When Mashkhur Zhusup

uses proverbs and sayings they undergo different changes due to author's speech skill. However, these changes do not affect the overall meaning, the object, the idea which is the main link of the whole expression.

In this regard, A. Kaydar writes: «We call invariants those types that are a consequence of proverbs and sayings various changes and which are used in practice only once or twice. There are no specific laws how to use them. Invariant changes are related to the skill of maintaining grace, effect of figurativeness and expressiveness, emotional-expressive power of expression». [7]

The essence of proverbs and sayings is disclosed together with the national philosophical inference and correspondence of figurative poetic methods, that is why being the main component of stylistic evaluation category it covers the most important (profitable) part of stylistic impact. The main purpose to use proverbs and sayings in Mashkhur Zhusup's works can be revealed in the abovementioned reasons.

A poet in his poems does not always apply the original form of proverbs and sayings. In some cases, their content, even slightly, is changed. For example, popularly version of proverb «Kedeidin bir toigany - shala baiygany» is changed by author into «Bir toigan - shala bailyk». The same is with the second proverb «Zhaqsy soz zhan semirtedi». The author used it as «Zhan semirer zhaqsy sozge».

«Bir toigan - shala bailyq» degen qazaq,

Qyzygyp toigandyqqa qalar zhatyp» [8].

(A full stomach is not a limit to aspirations,

But a pathetic whim of narrow-minded people)

\section{Zhan semirer zhaqsy sozge,}


Korkeidim khatyndy oqyp, sol bir zhassap [9].

(Song and line heal a steppe-dweller's soul,

And your rare letters open our eyes).

The meaning of proverbs and sayings does not suffer; the poet only shows the expressiveness of thought.

The meaning of the proverb «Birinshi bailyq - densaulyq, ekinshi bailyq - aq zhaulyq, yshinshi bailyq - on saulyq» is used in this way:

\section{Berip qoidy ayamai densaulyqty,}

Otyrgyzyp qassyna aq zhaulyqty.

Sausan bie, artuga tuige berip,

Qotanynnan orgizip zhuz saulykty [10].

(The Supreme Being gave me health,

My way is filled with love and happiness.

And when steppe dweller's back is strong and united,

Wealth will flow into his house).

The same is with the saying "Tesik monshaq zherde qalmas»:

Deimisin tesilgen tas zherde qalar,

Shamshyraq Khaq zhandyrgan saulap zhanar.

Assyl, zhassyq ekenin bilmese de,

Shelekke taguga bireu alar [15].

(Stones are considered steppe weeds,

Allah forgot to give his gold love to them.

But in steppe-nomad's uncomplicated economy,

Stone - the best labour tool).

The author changes the saying "Zhetim korsen zhebei zhur» in this way:

Zhetim korsen, zheksuryn korme!-deidi..

Tileshini telmirtip zhurme!-deidi.

Shaitan turar: «Berme!» - dep zhagalasyp,

Onyn aitqan tiline erme! - deidi [10].

(Do not look disdainfully at an orphan,

Help a beggar.

Muffle all vile in you, see the light,

Everything is given to us by God, remember it for the rest of your days).

In these lines the poet does not damage the content or structure of proverbs and sayings, our national heritage, and we can see it exaggerate and intensify their essence after such a masterful transformation.

The expression «Bul kunde altyn azyp zhez bolypty» means that «the importance of the word disappeared», because the popular variant is: «Az soz - altyn, kop soz - komir». Mashkhur Zhusup uses a metonymic device to avoid this repetition.

Batshagar sonyn ushin zhurgen olmei,

Shara ne basqa tusse, pende konbei?! 
Zhalganda arbir turli qylgan istin,

Adassar: on-teressin pende bilmei [10].

(Everything in this world is losing the price,

Even the words of the wise are heeded as to chatter).

Mashkhur Zhusup shows the meaning of the saying «basqa tusse - baspaqshyl» in the lines of the mentioned poem.

\section{Zhamannan - boz qalady, zhaqsydan - soz,}

Dunienin kelui onai, ketui tez [10].

(High-sounding word and passionate line

Still grief lightening the soul with candles).

In Mashkhur Zhusup's teachings we learned that the main purpose of human life is to return to Basic Origins. In this life people do their duty showing someone their way. It is very difficult to understand this basic purpose of life. People want to live a life full of meaning; they want to leave behind a lot of good deeds. Poet conveys this idea through proverbs "Zhamannan - boz, zhaqsydan -soz qalady». For the poet calico is life, and the word is teaching actions, behavior sample. As the author says, the transience of life is not so annoying, you need to live it interesting, and only if a person's life is full of meaning it will be substantial. And this is the freedom of choice of the individual. At this point the poet does not change the main idea of the proverb «Zhaqsynyn aty olmeidi, galymnyn haty olmeidi», but only changes its structure.

$$
\begin{aligned}
& \text { Aldy-arty bul dunienin - qarangy tun, } \\
& \text { Umit bar - bolar degen bir zharyq kun. } \\
& \text { Qur bosqa tekke aigailap zoryqpaiyn, }
\end{aligned}
$$

Zhayaudan shan shyqpaidy, zhakgyzdan un [10].

(Darkness hides all the roads and paths without the moon,

Sadness fills every corner of the soul without a song).

Mashkhur Zhusup slightly changes the structure of proverbs popularly known as «Zhayaudyn shany shyqpas, zhalgyzdyn yni shyqpas". In the passage of the poem we see the image of the poet who is upset by the fact that there is no soul that could understand a word, and there was nothing that could please. Seeing different absurd deceit in this life, he equates life to the dark night. majority.

Showing these vexations, he is blue about the fact that he is completely alone, that can not withstand the

«Ash atassyn tanymas»-degen soz bar,

Auzyna ne tisse de baldai tatyr [10].

Creating an image of the hero in his work, the poet uses the popular saying without any changes.

Qulagynda tessik zhoq bul kunge zhan,

Sanyrauga salem bersen: «Atan bassy!» [10].

Mashkhur Zhusup uses unchanged popular known saying «Sanyrauga salem bersen, atannyn bassy deidi»

«Toyam»,-dessen, bolassyn zhamanatty,

\section{Toigan toqtyq buzady adamzatty.}

«Zhokka-shukir, azyna-qanagat!»-dep,

Auel bastan keshirip, aitqan, ani! [10].

(Dangerous illness came on human soul,

It shielded people honor with livestock and cereal,

Even Allah servants measure the Holy Qur'an Sura 
With the weight of paid ram).

The words of the poet «Toigan toqtyq buzady adamzatty» are consonant with Abai's words then turned into a proverb: «Tamagy toqtyq, koilegi koktik - azdyrar balasyn adam».

\section{Ten tenin olzhalamak, tezek qabyn,}

Bolmaidy sagan endi eshkim qumar [10]

The poet's phraseological unit «Ten tenin olzhalamak, tezek qabyn» is popularly known as «ten tenimen, tezek qabymen». The poet gets invariant sayings having created stylistic feature adding the word olzhalamaq. We see that having changed proverbs and sayings show their characteristic features when they are used in an invariant form. Undergoing these changes and manifesting itself with each face, being the basis for the conservation of the nominative form, the unity of meaning and content is inextricably linked to the logical conclusion. "Tulkinin kyzyldygy ozine sor» (Tuylkinin kyzyly ozine sor); "Altyndy pulyn bilmei zherge shashqan» (Qolda barda altynnyn qadiri zhoq); "Zhaqsyny ozi bolgan kore almagan, Bireudi kyndemese zhure almagan» (Oz zhurtyn zhaqsy bolsan kyndeidi, Zhaman bolsan zhyndeidl); "Tyzu agash bolady yyge tireu» (Tyzu agash yyge tireu, tyzu zhigit elge tireu); "Adamga pale - tilden, beinet kozden» (Basqa pale - tilden) etc. Here emotionality of idioms increases, their former added meanings develop and poet's own manner is displayed. The idiom "beinet - kozden»" in the example "Adamga pale - tilden, Beinet - kozden» is not used now. Mashkhur Zhusup in his poem «Zhayau qyl, napsindi atqa mingizbey baq, Koz sonynan konildi tizgindep baq» reveals the meaning of the idiom «beinet - kozden». In other words he highlights the countless committed by people sins, the possibility to carelessly commit deeds that contradict Shari'ah. It is possible to notice that Mashkhur Zhusup in his poems often uses the Quran and Hadith, it is also possible to notice that he took the content of the Hadith related to the concept of «Lascivious eye». Linguistically the poet joined two different parts of the idiom and used contamination.

2. In Mashkhur Zhusup's poems there are words which sphere of use is large. This is axiological words, typical for the whole human language system. Number of words denoting the key concepts include phraseological units formed with words konil (mood).

Let's look at the use of the phraseological unit "Konil kiri" (in the meaning of sadness, sorrow):

\section{Konilde zhatnqan kirindi}

Ottaiy ystyk soz zhoyar (Proverb).

(A decade of sea of sadness and sorrow,

Leaves its traces in songs and kyuis). (Proverb)

Aspanda ai bolmasa, adasady

Konildi kotermese, kir basady (Folk song).

Dynie kirin zhuynyp,

Korinip oyga koz salar (Abai).

-Kapir-antqa, musylman tilge nansyn,

Konil kiri aytumen ketsin, barsyn! [15].

(Not keeping vow inviolate, a Muslim believes in word

Since the word treats and injures).

Zhyrgenmen ne bitirdim tiri bolyp,

\section{Konildin tazarmagan kiri bolyp [15].}

(Songs and knowledge still human sorrow,

Life is hell for a Kazakh without music word).

\section{- Zhuiriktin alu- ushin aschy terin,}

Ter shyqqan son tarqatar ishtin sherin.

Gul zhuzdi, Shyryn sozdi naz ninnan,

Soz qozgap, ketireyik konil kirdi [15].

(It is difficult to compete with a master of word,

With sound line he cannot be surprised, I must admit.

There are no losers in the dispute about the truth,

Heart is being filled with joy, sadness disappears.)

The idiom «Konil kiri» in Abai's poem is the collocation «Dunie kiri» and is used in the sense of «thirst for new life», and in Mashkhur Zhusup's poem it is consonant with the variant created by people. And here you can notice that even if 
Mashkhur Zhusup's style is not so different from the people's one, it has its own peculiarities. Through the collocation "soul aftertaste» the poet, in one case, shows the necessity to express sincere sadness, resentment, then in another, he expresses sincere dissatisfaction with own actions, and uses this expression with different stylistic purposes. Here he is taking his soul aftertaste created metaphorical combination.

Here are the phraseological units used by Mashkhur Zhusup in his works featuring the word «mood, sadness» to express the human inner world and psychological state:

Bir yige kop qaraymyn tamasha etip ,

Ustaga sony salgan konilim ketip [10].

Konili ketu - pay attention, raise of interest.

"Kuligim bar!" - dep, men zhurmin konilim toyip [10].

Konili toyu -be glad, calm.

Mahabbat, marhabatly bolmagan son,

Uyz zhas qaldy konilim zamandastan [10].

Agaiynnan qalypty konil toqtap [15].

Konili qalu -take offence.

Zhalganda zhan emespin konilim osken [15].

Konili osu -be joyful.

Menmensigen talaydyn konilin bastym [15].

Ar turli toqtau aytyp konilin bastym [15].

Konilin basu -console, lead to conclusion.

Konildi, sheshemdi oylap, bole berdim [15].

Konil bolu -take care, help.

Qiqulap, elendetip, konilim boldin [15].

Here the expression «konil bolu» means 'to pay attention for a while".

Mashkhur Zhusup used these phraseological units in his works very often. They were used to express different moods of people and their actions.

It is known that human qualities come from the inner world of people. Mashkhur Zhusup's works are rich in description of the human qualities and among them there are enough units with the word "konil."

Kisinin konilin zhauqpagan [15].

Bireudi zhaqsy korip, zhyly tartsan,

Kirshiksiz bolyp konilin ak kaqazdai [10].

Korumen, konil kozben angarady [15].

Konilim bar shapagattan, kelse shamam [15].

Koniline maqtan kirmegen [15].

Samples that show the way to enrich the expressions with a new meaning, that linked the words which are not connected with each other, words with absolutely different meanings, and revived expressions originating from ancient times:

Konilin bir olik edi zhansyz zhatqan [10].

Konildin el qalmagan zhailauynda [15].

Or

Konilime erte qongan sozdin auyly [15].

Connecting both concrete and abstract concepts, national identity is shown and the collocations with high expression are created.

Because such words as «aul», «dzhailyau» are native Kazakh words used in Kazakhs everyday life.

Bir zherden eki konil shyqqandyqtan [15]. 
Phraseological unit eki konildin bir zherden shyguy (two wishes became one) shows the author's manner. Mashkhur Zhusup changes the saying known as bir zhennen qol, bir zhagadan bas shygar.

Konilimde saqtap zhurmin bir zhaz, bir qys [15].

In this collocation the poet behaves phlegmatic, he wants to show that he treats everything with equanimity.

Tausylmas, shashsan qansha, konil - bir ken [15].

Semantically the word "mood" is divided into several types and as a result of this poet found a way to get new expressive meaning. They are author's occasional use by Mashkhur Zhusup. These expressions do not only show the expressiveness of the literary language, but also pay attention to the new features of figurative means used by the poet, introduce new types of expressive names.

The poet's skills, occasional use, national knowledge of the poet's language personality are widely regarded in the scientific works by G.T. Karipzhanova [16], [17] and B.M. Kadirova [18].

They also demonstrate the reinforcement of compatibility, having increased the activity of the words in the diversity of components defining the word "mood", i.e. attributive components.

Zher alys bolganmenen, konil zhuyq [15].

Bolsa da konil qorqaq, qol batyr-dy [15].

Muratym bitpese de, konilim toq [15].

Mashkhur Zhusup, having used the word "mood" with verbs and given them a character of emphasis, receives the following collocations:

Sharq uryp, konilgen kezip, ar tarapty [15].

Baramyn toqtai almai, konil koship [15].

Zherlerge konilin suigen tusip zhurgen [15].

The poet considers that a man raises decency thinking about the power of the Supreme Being, increasing human faith in his infinity. He, therefore, calls to love the Supreme Being, and treat him with a pure soul, take him in own heart.

"Mood" is a linguistic unit that has conceptual meaning. "Mood" is used to describe the life of Kazakhs, express faith and belief, human emotions and feelings, a psychological state. The poet understands the word "mood" as a common name for concepts born as a result of regularity of such mental processes as analogy and association. It is a language reference unit to create phraseological units.

3. Attempts to introduce a new word into the components of phraseological units. Due to the fact that the structure of phraseological units is stable, adding the word does not allow anciently. But in poetry this phenomenon occurs very often and for meeting various requirements of poetic language such a thing is even legal. I. Kenesbayev: "In fiction literature, in its oral and written forms, there are times when any phraseological unit, taken from the nation, slightly expands or contracts, and is woven into the artistic text or poetic size ... and if these changes are formed due to conscious transformations, introduce extraneous words; such a phenomenon is called "distant" [11].

"Introduced tested words are not irrelevant deviation from standards if attaching they do not harm the unity of the meaning of idioms and are in harmony." [12].

All parts of speech produce a distant phenomenon occurring during the use of phraseological units and they are a means of forming phraseological variants. Distant phenomenon is also found in the phraseological units in Mashkhur Zhusup's works.

Tisindi alys zhauga kop qadaisyn,

Artynnan naiza, qylysh bek toyaisin [10].

Or

Qas pen kozdin, kirpiktin arasynda

Talaisyzga tiken bop til qadalar [15].

Sol siyaqty

Ol molda buryngydai bola almady,

Koniline kundege soz qona almady [15].

Ar zherde zhurt auzynda angime bop,

Qulaqtyn, estiginde, quryshy qansyn [15]. 
The author, in order not to disturb the harmony of his poem rhyme, trying, introduces a new word into a phraseological unit. Distant phenomenon does not damage the meaning of an idiom; on the contrary, merging with each other, they are in harmony.

Inshalla, zhazgan sozim bir de qalmas.

Bu loner titrim tugil, korde qalmas..

Bolat matin - qanzharmen tesilgen tas,-

«Tesik tas, -degen soz bar, -zherde qalmas» [10].

(All have been taught to be silent, the silence is in the steppe,

Only my tongue rings the tocsin.)

The poet equates his written lines, creations to strong like steel text. Tempering steel text, like a dagger, a piercing stone, the poet uses a folk saying and conveys it to the reader in order it does not disappear completely. And in this case, not to break a poem rhyme the poet uses distant method. Bolmasa zhaqsylyqtan esh narsemiz, Sorymyz sonda bizdin qaynaydy eken; Shahar zhaqqa tuzeydi endi betti; Qay zherinnen kelmei tur, aytshy, kuin; Tuzagyna bir zhurttyn tusip torly; Delebem ayqay shyqsa, keter qozyp; Ilinsem zhaqsylyqpen el auzyna; Aqynnyn shek keltirme til zhagyna, Ilinsen sau qalmaysyn tyrnagyna. In this context, the poet uses phraseological units that can undergo inversion, the components of which are located distantly. They do not break the unity of meaning. Even if occurring in the composition of phrsaeological units words do not pursue any stylistic purpose, they participate in the extension of meaning, adding expressiveness. Thus, we can say that a distant phenomenon forms phraseological variants.

\section{The use of phraseological units with changed word order.}

Inversion is the change of common order of related to each other words, parts of the sentence, and complex expressions in the sentence. Inversion (latin. Inversio - upturning, change, deviation) - 1) in a broad meaning: a change, a deviation from the usual use of the order of the sentence parts; 2) in a narrow meaning: deviation, change of the order of the sentence parts which do not depend on the changes in syntactic link. [13].

Due to the fact that free collocation is a genetic prototype of the idiomatic expression, order of words and components are closely linked with the norms of word forms in a free collocation, but it does not occur so often. This issue was also considered by scholars in the field of phraseology. For example, N.M. Shanski [14, 49-52.] believes that the distinction between the order of the components of a phraseological unit is one of the characteristics that distinguish it from free collocation.

It is not an inappropriate deviation from the linguistic standard. Exposure of components of phraseological units to inversion and change of their places increase their pragmatic potential and give expressive description. In general, the word order included in phraseological unit is concrete. Use of inversion is common in poetic lines of the poem. In this case there is an influence of poetic rhyme and it changes during the selection of rhyme to another word.

Mashkhur Zhusup also does not reject this regularity. The poet uses inversion not only to produce rhyme and rhythm, but also for the logical stress in a word, and pursuing stylistic-pragmatic purpose, he presents the main idea in the first line or at the beginning of a line. One of the most productive phenomena in Mashkhur Zhusup's language is the changes of common order of phraseological components and use of inversion. Using this method, peculiar to free word combinations, it is possible to notice a certain meaning in the phraseological phrase. From the dynamic point of view the change of the order of phraseological components, which appears in various forms, does not change the stress which in the initial form of the phrase fell on a specific component. Such influence of pragmatics and stylistics on inversion, in general, draws attention by means of a special order of the components. Syntactic use of inversion applied by Mashkhur Zhusup is defined as the use of means to enhance the expressiveness and to show a particular importance of the components.

Dunieden qalgan zhan zhoq ayap kushin,

Qairaumen shyqyr-shyqyr otyz tisin.

Aip, tauyp zhastanaiyn bosagasyn,

Moldany bala oqytqan qudai ushin [15].

(These mullahs are the children of their era,

Their word itches, gain is sweeter.)

The origin of the phrase "otyz tisin qayrau" is tisin qayrau (hold a grudge). Mashkhur Zhusup, regarding the idea of his poem, in order to reveal the image of grabbers, added the word "thirty" and increased semantic tone using interjections that indicate rattle sound. Even the thought of that Mullah teaches his child for money makes him indignant.

Reorder of phraseological component ignores the meaning of the expression, but draws readers attention, as the deviation from the standard is due to the fact that the places of the components are interdependent. Inversion of phraseological components is created by using the phraseological occasional basis, consisting of process of breaking conventional 
grammatical order of its components. The change of phraseological components gives a special expressive tone to a phraseological unit, increases its pragmatic potential.

Otyrmyn bu zhalgannan uzip kuder,

Zhetken son zher tayangan mezgilime [15]

Or

Tili zhoq ko mylqaular tyiysh zhatyr goi,

Qyzyl til, sen bassymda saldyn dauga [15].

(It is better hide and live without ears

Than being people's laughingstock).

Due to the fact that the structure of phraseological units is processed, there are no changes in their traditional meaning. Even if in this case phraseological units do not undergo transformation, due to poetic rhyme the order of components is changed. Such a change in word order is neither stylistic nor semantic change. We can see the purpose of the poet not to disturb the melody, the rhythm of the poem. Thus, we see that the use of inversion performs expressive-ideological function in the work. The change of meaning and external structure of phraseological units is considered to be poet's individual feature to use wealth of the language.

\section{Mashkhur Zhusup's popular quotations.}

The poet's phrases and popular quotations, which were born by the poet, spread among the people and found their use. For example:

1.Zhasymda gylym bar dep eskermedim.

(In my youth I did not think that science would become part of my life.)

2. Til oneri dertpen ten.

(Passion for art of words can be compared with disease).

3. Ar uyalar is qylmas aqyl zerek. (People of honor and mind are always accompanied by well-being).

4. Dosyna dostyk qaryz is. (Abai).

(Responsibility and common interests strengthen the friendship).

5. Oner - bilim bari de oqumenen tabylgan.

(Both art and science rest on knowledge)

6. Aurudan - ayagan kushtirek. (lbrai).

(Only worthless people turn away from helping the sick and weak)

Mashkhur Zhusup's works have deep and expressive phrases created after proverbs and sayings. Mashkhur Zhusup's quotations are similar to brief conclusions from his own life experience and perception of the world. Poet:

Bul atty zhoqtan bar gyp tanirim shashty,

Sozimdi zhurt syrga qyp qulaqqa asty.

Boitumar basqalarga bolgan sozim

Ozimdi qylmas tipti ayaq asty [9]

Zhel sozdin tunyp zhatqan kiltin ashtym,

Ar turli toqtau aityp, konilin bastym.

Buryngydan, songydan tuk qaldyrmai,

Uatyp, zhubatu goi menin qastym [9.].

Qylady shukir, sabyr bilgen adam,

Ashylyo zhurek kozi, korgen adam.

En aldy ulken bailyq -az kun omir,

Zhatady tort qulaqta olgen adam [9] 
(My songs are sung all over the steppe,

From the Altai Mountains to the banks of the Syr Darya.

They are both tocsin, and the messengers of light and struggle,

Blackthorn satellites of my troubled fate.

I found the keys and the word opened the name of its secrets,

Word can raise and lower to bottom.

It can lift your mood and still sadness,

Make enemies of friends and raise slaves off their knee).

\section{Birdei bop bu bazarda atlas pen boz,}

Zhok bolyp asylundy tanityn koz.

Belgili bud a bir dert ustamaly:

Zholygyp keken zhannyn qoqlqasy-soz [9].

(Both calico and satin are woven by one hand,

But some value, others give very cheaply.

Why? What? Where? When?

Answers will be given only by clever books and words).

From the standpoint of the structure and functions the poet offers a variety of new phraseological units and expressions Such phrases are often found.
Esti adam - qanagatty.
Qanagatty adam tiyanaqty.
Tiyanaqty adam konterli.
Konterli adam qaigysyz.
Qaigysyz adam baqytty
Endeshe esti adam baqytty bolady [15].

The feeling of contentment in human life is an indication of his consciousness; the poet concludes that satisfaction with everything makes a person happy. He reveals deeper meaning of folk proverb "Qanagat - qaryn toygyzar" ("Satisfaction will feed your stomach").

Tynyshtyq kerek bolsa, bir zhanyna,

Ozindi gylym birlan onerge sal [15].

Or

Ne narse paryz bolsa, gylym-paryz,

Gylym bilsen, oterler qansha qaryz [15].

As a patriot of his time, the poet urges people to be educated. The poet understands being educated is our duty. He states that science is necessary, above all, for the tranquility of the human soul. And there is definitely the truth.

Kedei baidan tilenip borysh algany:

Oz-ozinen darga assylgany [15].

Or

Bul kunde til soilemes, aqsha - sheshen,

Zhugirer bai zhumsasa, ne men, ne sen.

Duniege dinin satqan adamdardan 
Alys zhur, boi suytyp aman-essen [15].

It should be noted that these words conform the current problems.

Thus, the method to update phraseological units, which is used by the poet, is created on the basis of the language of oral art, the poet proves the comparison of his author's popular quotations with the language of Kazakh oral literature, and considers it is a contribution to the enrichment of Kazakh phraseology.

\section{Conclusion}

To summarize, in Mashkhur Zhusup's works we have seen variety of occasional use of phraseological units in terms of the used methods. The poet used these different methods for the main ideas of his poem. Choosing the most necessary from the nation-wide idioms, if possible, he used them in various forms. Using phraseological units in his poems, he gives them stylistic coloring and complicates their functions. Updating, changing, processing idioms, filling them with expressive words, he gives to contextual meaning of phraseological units emotional-expressive tone, changing their figurative properties he enhances stylistic function, reveals pragmatic purpose.

\section{REFERENCES}

1. Bowman, M., Debray, S. K., and Peterson, L. L. 1993. Reasoning about naming systems. .

2. Ding, W. and Marchionini, G. 1997 A Study on Video Browsing Strategies. Technical Report. University of Maryland at College Park.

3. Fröhlich, B. and Plate, J. 2000. The cubic mouse: a new device for three-dimensional input. In Proceedings of the SIGCHI Conference on Human Factors in Computing Systems

4. Tavel, P. 2007 Modeling and Simulation Design. AK Peters Ltd.

5. Sannella, M. J. 1994 Constraint Satisfaction and Debugging for Interactive User Interfaces. Doctoral Thesis. UMI Order Number: UMI Order No. GAX95-09398., University of Washington.

6. Forman, G. 2003. An extensive empirical study of feature selection metrics for text classification. J. Mach. Learn. Res. 3 (Mar. 2003), 1289-1305.

7. Brown, L. D., Hua, H., and Gao, C. 2003. A widget framework for augmented interaction in SCAPE.

8. Y.T. Yu, M.F. Lau, "A comparison of MC/DC, MUMCUT and several other coverage criteria for logical decisions", Journal of Systems and Software, 2005, in press.

9. Spector, A. Z. 1989. Achieving application requirements. In Distributed Systems, S. Mullender

10. [1] Maclean N. From action to image: Theories of lyric in the 18 th century // Critics and criticism. Lon., 1975. P. 417.

11. [2] Morris Ch.W. Foundations of the theory of signs//Semiotics. M., 1983.

12. [3] Fry P. H. The poet's calling in the English ode. L., 1980. P. 25.

13. [4] Asher R.E. The encyclopedia of language and linguistics. - Oxford: Oxford University Press, 1994.

14. [5] Roisenson L.I. Reproducibility as a sign of phraseology - Samarkand, 1972. - P. 185.

15. [6] Karibzhanova A.O. Mashkhurtanu. - Pavlodar: Kereku, 2011. - P. 182.

16. [7] Kaidarov A.T. Issues of Kazakh language historical lexicology - Almaty, 1983. - P. 198.

17. [8] Mashkhur - Zhusip Kopeiuly. Selected poems. Pavlodar: EKO, 2005. - 2 v. - P. 456.

18. [9] Mashkhur - Zhusip Kopeiuly. Writings. - Pavlodar: EKO, 2007. - P. 485.

19. [10] Mashkhur - Zhusip Kopeiuly. Selected poems. Pavlodar: EKO, 2005. - 1 v. - P. 425.

20. [11] Kenesbayev I. Phraseological dictionary of Kazakh Language - Almaty: Gylym, 1977. - P. 712.

21. [12] Ualiev N. Phraseology and linguistic norm - Almaty, 1998. - P. 128.

22. [13] Tretyakova I.Y. The inner form of occasional phraseology // Problems of semantics and functioning of language units of different levels: Materials of the II regional conference. - Ivanovo, 2004. - P. 110-114.

23. [14] Shansky N.M. Phraseology of modern Russian language. - M .: Higher School, 1969. - P. 205.

24. [15] Mashkhur - Zhusip Kopeiuly. Writings. - Pavlodar, EKO, 2008. - 5v. - P. 425.

25. [16] Karibzhanova G.T. The nature of national outlook in the works of Mashkhur Zhusip // "East Slavic languages and literature at historic and cultural context: cognitive linguistics and conceptual study" Ukraine. Kiev, 2012.- P. 116-121 
26. [17] Karibzhanova G.T. National coloring in the works of Mashkhur Zhusup // Philology. Theory and practice. Tambov c.: Gramota, 2012. № 4. P. 69-72.

\section{Author' biography with Photo}

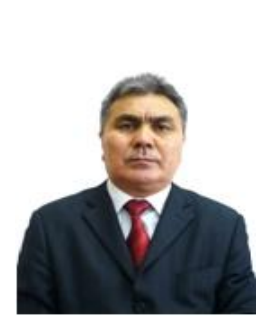

Aytmukhamet Kasymbayevich Trushev, Professor, Doctor of Philological Sciences.

Education: N.K. Krupskaya Semipalatinsk Pedagogical Institute, 0307 Kazakh Language and Literature (1981)

Courses taught: Introduction to Turkic Philology; Philosophical and Methodological Problems of Linguistics; Basics of Theory and History of Language; Modern Kazakh Lexicology

Professional experience: 43 years

Publications: 776

Field of research: Linguistics

Professional achievements: Sh. Ualikhanov Prize (2003), Best Lecturer (2005), Researcher of the Year (2009); scientific grant from the MES for special contribution to the development of science and technology (2011-2012); Badge for Merits in Development of Science in the Republic of Kazakhstan (2005); Best HEI Lecturer (2006); Professor in Linguistics (conferred by Committee for Control in the Field of Education and Science, Ministry of Education and Science of the RK) (2010). Author of 73 research and methodological works: monographs, textbooks, study guides, and 776 research papers. Professional development courses: Pedagogical, Information and Communication Technology of Distance Education (2010); Workshop on Thomson Reuters for Scientific Research (2012).

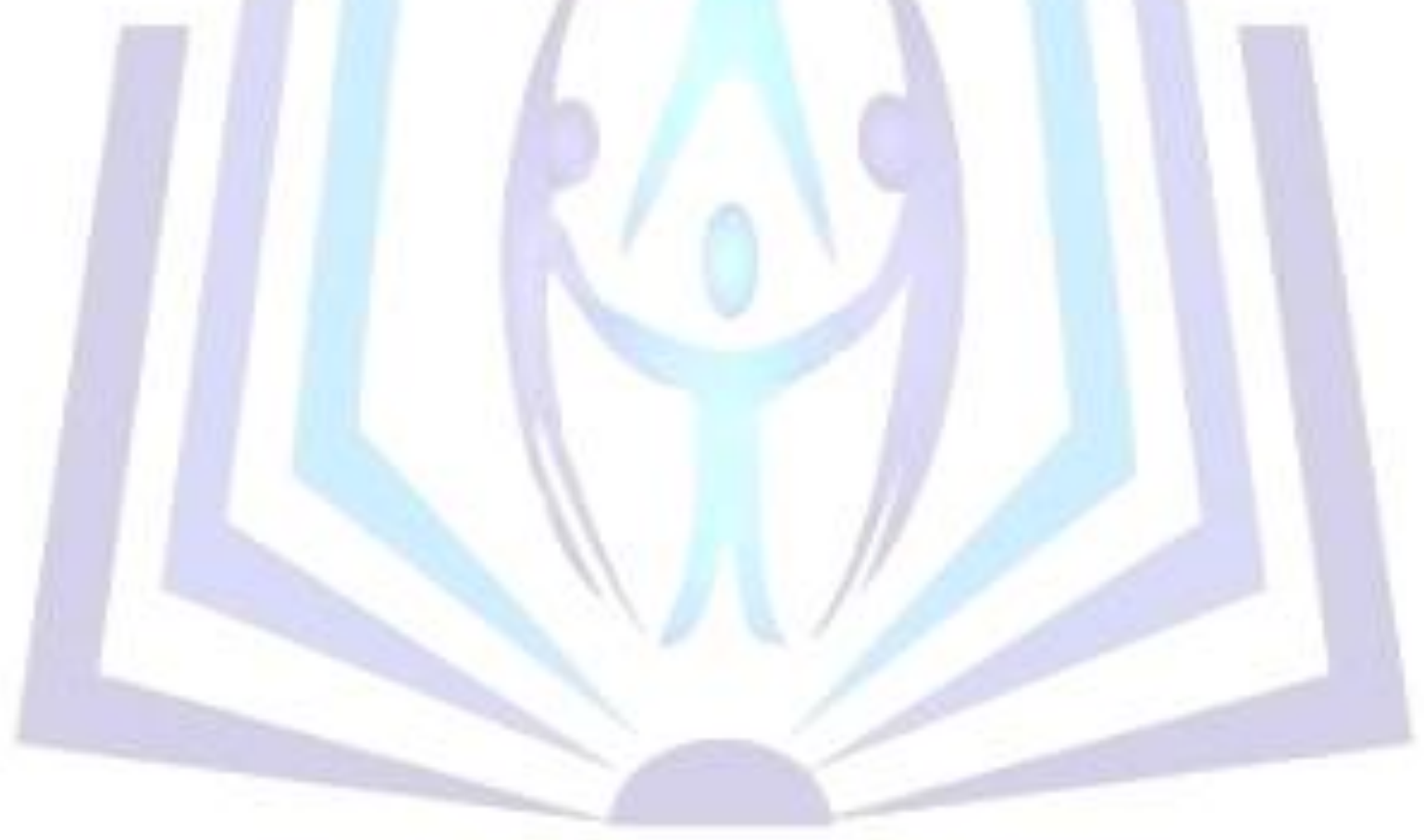

